\title{
Pengaruh Keefektifan Pengendalian Internal, Ketaatan Aturan Akuntansi, Kesesuaian Kompensasi, Moralitas Manajemen, dan Budaya Etis Organisasi Terhadap Kecenderungan Kecurangan Akuntansi
}

\author{
Fanny Yulia ${ }^{1}$ Rita Anugerah ${ }^{2}$, Nur Azlina ${ }^{*}$ \\ ${ }^{1}$ Fakultas Ekonomi dan Bisnis Universitas Riau; fanny.yuliao118@student.unri.ac.id \\ 2Fakultas Ekonomi dan Bisnis Universitas Riau; rita.anugerah@ lecturer.unri.ac.id \\ 3Fakultas Ekonomi dan Bisnis Universitas Riau; nur.azlina@lecturer.unri.ac.id*
}

\begin{abstract}
Abstrak
Penelitian ini bertujuan mengetahui pengaruh keefektifan pengendalian internal, ketaatan aturan akuntansi, kesesuaian kompensasi, moralitas manajemen, dan budaya etis organisasi terhadap kecenderungan kecurangan akuntansi. populasi dalam penelitian ini adalah pegawai di 33 organisasi perangkat daerah Kota Pekanbaru. Sedangkan responden terdiri dari Kepala bagian keuangan, kepala sub bagian keuangan, dan bendahara pengeluaran yang berjumlah 68 orang. Metode penentuan sampel yang digunakan dalam penelitian ini adalah sampel jenuh. Hasil penelitian membuktikan bahwa (1) keefektifan pengendalian internal berpengaruh terhadap kecenderungan kecurangan akuntansi dengan tingkat signifika o,o17 (2) ketaatan aturan akuntansi berpengaruh terhadap kecenderungan kecurangan akuntansi dengan tingkat signifikan o,014 (3) kesesuaian kompensasi berpengaruh terhadap kecenderungan kecurangan akuntansi dengan tingkat signifikan o,oo6 (4) moralitas manajemen berpengaruh terhadap kecenderungan kecurangan akuntansi dengan tingkat signifikan o,039 (5) budaya etis organisasi berpengaruh terhadap kecenderungan kecurangan akuntansi dengan tingkat signifikan o,o14. Berdasarkan hasil uji koefisien determinasi atau Adjusted $R^{2}$ sebesar 0,405 menunjukkan bahwa kecenderungan kecurangan akuntansi dipengaruhi 40,5\% oleh keefektifan pengendalian internal, ketaatan aturan akuntansi, kesesuaian kompensasi, moralitas manajemen dan budaya etis organisasi. Sedangkan sisanya 59,5\% dipengaruhi variabel lain.
\end{abstract}

Keywords: Kecenderungan Kecurangan Akuntansi; Pekanbaru

\begin{abstract}
This study aims to determine the effect of internal control effectiveness, compliance to accounting rules, suitability of compensation, management morality and the ethical culture of the organization against on the tendency of accounting fraud. population in this study were employees in 33 organizations of Pekanbaru district. Whereas the respondents consisted of head of finance department, head of sub finance department, and spending treasurer of 68 people. The method of determining the sample used in this study is saturated sampling. The result of research showed that (1) the internal control effectiveness influenced the tendency of accounting fraud with significant value o,o17 (2) the compliance to accounting rules influenced the tendency of accounting fraud with significant value 0,014 (3) suitability of compensation influenced the tendency of accounting fraud with significant value o,oo6 (4) management morality influenced the tendency of accounting fraud with significant value 0,039 (5) the ethical culture of the organization influenced the tendency of accounting fraud with significant value o,o14 . Based on the results of determination coefficient test or Adjusted R2 of 0.405 indicates that the tendency of accounting fraud
\end{abstract}


influenced 40,5\% by internal control effectiveness, compliance to accounting rules, suitability of compensation, management morality and the ethical culture of the organization. While the remaining 59,5\% influenced by other variables.

\title{
Keywords: Tendency of accounting fraud; Pekanbaru
}

\author{
${ }^{*}$ Korespondensi penulis
}

\section{PENDAHULUAN}

Kecenderungan Kecurangan Akuntansi menjadi problematika yang menjadi pusat perhatian seluruh penjuru dunia sebagai dinamika yang sering terjadi. Salah satu ciri terdapat kecenderungan kecurangan akuntansi ditandai dengan adanya tindakan dan kebijakan yang disengaja, dimana tindakan tersebut bertujuan untuk berbuat curang. Seperti, manipulasi, mark up, dan penyalahgunaan aset maupun korupsi. Kecenderungan kecurangan akuntansi sudah kerap terjadi, bahkan sampai ke level bawah. Banyak kasus terkait kecenderungan kecurangan akuntansi yang sudah tersebar luas melalui media massa, sehingga masyarakat menganggap bahwa kecenderungan kecurangan akuntansi ini bukan suatu rahasia lagi. Terdapat dua jenis kesalahan penyajian yaitu kecurangan dan kekeliruan. Istilah kecurangan berbeda dengan istilah kekeliruan (Simanjuntak dkk., 2015). Jika tindakan tersebut dilakukan secara sengaja, maka disebut kecurangan dan jika tindakan tersebut dilakukan secara tidak sengaja, maka disebut kekeliruan.

Menurut The Association of Certified Fraud Examines (ACFE) (2016) kecurangan merupakan segala sesuatu yang secara lihai dapat digunakan untuk mendapatkan keuntungan dengan cara menutupi kebenaran, tipu daya, kelicikan atau mengelabui dan cara tidak jujur yang lain. Dari perspektif kriminal, kecurangan akuntansi dikategorikan sebagai kejahatan kerah putih (white-collar crime). Salah satu tindak kecurangan (fraud) yang terjadi di Indonesia adalah korupsi. Beberapa survei indikator global menunjukkan bahwa korupsi menempati urutan pertama dalam laporan Global Competitiveness Index 2016-2017 oleh Wold Economic Forum dengan persentase 11,6\% kemudian disusul inefisiensi birokrasi menempati urutan kedua dengan persentase $9,3 \%$ salah satu sumber inefisiensi dan sebagai faktor penghambat usaha di Indonesia. Bahkan data 2017 dari Indonesia Corruption Watch memperlihatkan aparat sipil menduduki urutan teratas sebagai pelaku korupsi, diikuti DPRD, dan kepala daerah. Berdasarkan hasil survey Transparency International Indonesia merilis Indeks Persepsi Korupsi (IPK) atau Corruption Perceptions Index (CPI) pada 2018. Hasilnya, Indonesia berada di posisi ke-89 dengan skor 38. Hal ini dibuktikan dengan banyaknya kasus penyalahgunaan dan penggelapan anggaran Negara di pemerintahan.

Salah satu contoh kasus yang terjadi adalah kasus korupsi penyelewengan dana APBD yaitu video wall Pemko Pekanbaru pada tahun 2020 senilai 3,9 miliar di Dinas Komunikasi Informasi, Statistik dan Persandian (Diskominfotik) Kota Pekanbaru yang dilakukan oleh VH, selaku Pejabat Pelaksanaan Teknis Kegiataan (PPTK) proyek pengadaan video wall, dan AMI, Direktur CV Solusi Arya Duta, selaku rekanan penyedia video wall. Pada pelaksanaan pengadaan video wall dengan anggaran yang bersumber dari APBD Kota Pekanbaru sebesar Rp 4.448.505.418 itu. Tersangka VH selaku PPTK melakukan pembelian barang menggunakan e-katalog kepada CV Solusi Arya Prima, sebanyak 15 unit. Namun barang yang dibeli tidak sesuai dengan kontrak. Karena barangbarang datang ternyata tidak dilengkapi 
dengan jaminan garansi dari pabrik serta buku petunjuk pemakaian dan pemeliharaan dalam bahasa Indonesia. Atas perbuatannya, kedua tersangka dijerat dengan pasal 2 ayat 2 Jo Pasal 18 atau subside Pasal 3 Jo Pasal 18 undang-undang (UU) Nomor 31 Tahun 1999 sebagaimana diubah dan ditambah dengan UU Nomor 20 Tahun 2001 tentang Pemberantasan Tindak Pidana Korupsi.

Terdapat berbagai faktor yang mempengaruhi kecenderungan kecurangan akuntansi antara lain keefektifan pengendalian internal, ketaatan aturan akuntansi, kesesuaian kompensasi, moralitas manajemen, dan budaya etis organisasi.

Keefektifan Pengendalian internal merupakan proses yang dijalankan untuk memberikan keyakinan memadai tentang pencapaian keandalan laporan keuangan, kepatuhan terhadap hukum, efektivitas, dan efesiensi operasi (Wilopo, 2006:27). Perlunya pengawasan terhadap pengendalian internal digunakan untuk memastikan pengendalian internal berjalan dengan efektif atau tidak. Suatu instansi sebaiknya memiliki pengendalian internal yang efektif, dengan adanya pengendalian internal yang efektif diharapkan mampu mengurangi tindakan kecurangan akuntansi yang merugikan instansi. Hasil penelitian yang dilakukan Fitri (2016) yang menyatakan bahwa keefektifan pengendalian internal tidak berpengaruh secara signifikan terhadap kecenderungan kecurangan akuntansi, Meliany (2013) menyatakan bahwa keefektifan pengendalian internal berpengaruh secara signifikan terhadap kecenderungan kecurangan akuntansi.

Selain keefektifan pengendalian internal, ketaatan aturan akuntansi juga merupakan faktor yang mempengaruhui kecenderungan kecurangan akuntansi. Menurut Thoyibatun (2012) Ketaatan Aturan Akuntansi merupakan suatu kewajiban dalam organisasi untuk mematuhi segala ketentuan atau aturan akuntansi dalam melaksanakan pengelolaan keuangan dan pembuatan laporan keuangan agar tercipta transparansi dan akuntabilitas pengelolaan keuangan dan laporan keuangan yang di hasilkan efektif, handal serta akurat informasinya. Hasil penelitian yang dilakukan Irwansyah (2018) mengatakan bahwa ketaatan aturan akuntansi berpengaruh negatif terhadap kecenderungan kecurangan akuntansi. Sedangkan Fitri (2016) menyatakan bahwa ketaatan aturan akuntansi tidak berpengaruh secara signifikan terhadap kecenderungan kecurangan akuntansi.

Kesesuaian Kompensasi merupakan faktor yang mempengaruhi terjadinya Kecurangan Akuntansi. Kecurangan terjadi karena ketidaksesuaian imbalan yang diterima pegawai dengan yang dikerjakan sehingga mengakibatkan pegawai untuk melakukan tindak kecurangan. Pemberian kompensasi kepada karyawan akan membantu perusahaan untuk mencapai tujuan dan memperoleh, memelihara dan menjaga karyawan dengan baik. Sebaliknya tanpa kompensasi yang cukup (sesuai) karyawan yang ada akan sangat mungkin untuk meninggalkan perusahaan. Akibat dari ketidakpuasan pembayaran yang dirasa kurang akan mengurangi kinerja, meningkatkan keluhan-keluhan, mogok kerja dan mengarah kepada tindakan-tindakan fisik dan psikologis seperti meningkatnya derajat ketidakhadiran dan kecurangan. Menurut Veitzal (2011) Kesesuaian kompensasi merupakan sesuatu yang diterima perusahaan sebagaimana disetujui oleh perusahaan. Pemberian kompensasi merupakan salah satu faktor yang berpengaruh terhadap kecenderungan kecurangan akuntansi. Hasil penelitian yang dilakukan oleh Melaniy (2013) menyatakan bahwa Kesesuaian Kompensasi berpengaruh secara signifikan terhadap Kecenderungan Kecurangan Akuntansi. Namun Irwansyah (2018) melakukan penelitian di Perusaha- 
an Distributor Kota Bengkulu, hasilnya menunjukkan bahwa Kesesuaian Kompensasi tidak berpengaruh negatif terhadap Kecenderungan Kecurangan Akuntansi.

Faktor lain penyebab maraknya tindak kecurangan akuntansi adalah moralitas manajemen. Menurut Lilik (2016) moralitas manajemen adalah suatu sikap atau tindakan yang diambil oleh pihak manajemen untuk mengambil keputusan dan menyajikan laporan keuangan sesuai dengan standar akuntansi yang berlaku. Hasil penelitian yang dilakukan oleh Alou, S. D. (2017) mengatakan Moralitas Manajemen berpengaruh terhadap Kecenderungan Kecurangan Akuntansi. Namun berbeda dengan penelitian yang dilakukan oleh Irwansyah (2018) menunjukkan bahwa Moralitas Manajemen tidak berpengaruh negatif terhadap Kecenderungan Kecurangan Akuntansi.

Dan Budaya etis organisasi juga merupakan faktor yang dapat memengaruhi terjadinya kecenderungan kecurangan akuntansi. Menurut Robbins (2008) budaya etis organisasi adalah suatu persepsi bersama yang dianut oleh anggota anggota organisasi itu, sehingga persepsi tersebut menjadi suatu sistem dan makna bersama di antara para anggotanya. Hasil penelitian yang dilakukan oleh Fachrunnisa (2015) Budaya Etis Organisasi berpengaruh signifikan terhadap Kecenderungan Kecurangan Akuntansi. Namun berbeda dengan penelitian yang dilakukan Sari, Novita (2018) menunjukkan bahwa Budaya Etis Organisasi tidak berpengaruh signifikan terhadap Kecenderungan Kecurangan Akuntansi.

Berdasarkan penjelasan diatas peneliti tertarik untuk meneliti kembali tentang "Pengaruh Keefektifan Pengendalian Internal, Ketaatan Aturan Akuntansi, Kesesuaian Kompensasi, Moralitas Manajemen, dan Budaya Etis
Organisasi Terhadap Kecenderungan Kecurangan Akuntansi”.

\section{METODE}

Penelitian ini dilakukan pada OPD yang terdaftar di Kota Pekanbaru. Organisasi Perangkat Daerah (OPD) dapat didefinisikan sebagai pelaksana fungsi eksekutif yang harus berkoordinasi agar penyelenggaraan pemerintah berjalan dengan baik. Organisasi Perangkat Daerah (OPD) Kota Pekanbaru berjumlah 33 OPD yang terdiri dari 1 Sekretariat Daerah, 1 Sekretariat DPRD, 1 Inspektorat, 23 Dinas, dan 7 Badan. Untuk kuesioner penelitian ini direncanakan dibagikan kepada responden yaitu Kepala Bagian Keuangan, Kepala Sub Bagian keuangan, dan Bendahara pengeluaran, dan dikembalikan kepada penulis dalam waktu satu bulan.

Populasi dalam penelitian ini adalah OPD (Organisasi Perangkat Daerah) yang ada di Kota Pekanbaru.Sampel adalah bagian dari jumlah dan karakteristik yang dimiliki oleh populasi tersebut.Teknik pengambilan sampel yang digunakan dalam penelitian ini adalah teknik sampling jenuh. Istilah lain dari sampel jenuh adalah metode sensus. Sugiyono (2014:85) mengatakan bahwa sampling jenuh adalah teknik penentuan sampel bila semua anggota populasi digunakan sebagai sampel.

Responden dalam penelitian ini adalah Kepala Bagian Keuangan, Kepala Sub Bagian Keuangan, dan Bendahara pengeluaran dari 33 OPD di Kota Pekanbaru. Responden tersebut dipilih dikarenakan Kepala Bagian Keuangan, Kepala Sub Bagian Keuangan, dan Bendahara pengeluaran bertanggung jawab terhadap laporan keuangan dan bertanggung jawab terhadap hasil informasi akuntansi yang disediakan sehingga dapat memberikan informasi yang dibutuhkan oleh peneliti.

\section{HASIL dan PEMBAHASAN}




\section{Hasil}

\section{Uji Normalitas}

Tabel 1. Hasil

Pengujian Normalitas Data

\begin{tabular}{|l|l|r|}
\hline \multicolumn{2}{|l|}{} & $\begin{array}{r}\text { Unstandardi } \\
\text { zed Residual }\end{array}$ \\
\hline $\mathrm{N}$ & Mean & 62 \\
\hline \multirow{2}{*}{$\begin{array}{l}\text { Normal } \\
\text { Parameters }{ }^{\mathrm{a}, \mathrm{b}}\end{array}$} & Std. Deviation & .0000000 \\
\hline \multirow{2}{*}{$\begin{array}{l}\text { Most Extreme } \\
\text { Differences }\end{array}$} & Absolute & .079 \\
\cline { 2 - 3 } & Positive & .079 \\
\cline { 2 - 3 } & Negative & -.045 \\
\hline Kolmogorov-Smirnov Z & .623 \\
\hline \multicolumn{2}{|l|}{ Asymp. Sig. (2-tailed) } & .832 \\
\hline
\end{tabular}

a. Test distribution is Normal.

b. Calculated from data.

Sumber: Data output SPSS 25,2020

Sesuai dengan uji KolmogrovSmirnov yang ditunjukkan oleh Tabel 1. tersebut, maka diperoleh nilai signifikansi unstandarlized residual atau Asymp.Sig. (2-tailed) sebesar 0,832 lebih besar dari 0,05. Hasil pengujian ini menunjukkan bahwa nilai residual terdistribusi normal karena nilai signifikansinya lebih besar dari 0,05. Dengan demikian, maka hasil penelitian ini dinyatakan dapat diterima karena data yang dianalisis telah memenuhi kriteria uji normalitas.

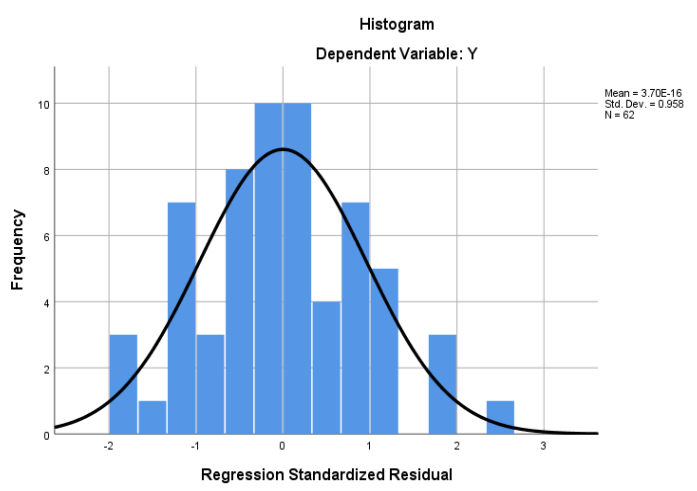

Gambar 1. Uji Normalitas Histogram

(Sumber : Data Output SPSS 25, 2020)

Berdasarkan gambar histogram di atas menunjukkan bahwa data terdistribusi secara normal karena bentuk kurva memiliki kemiringan yang cenderung imbang dan kurva mendekati pola distribusi normal.

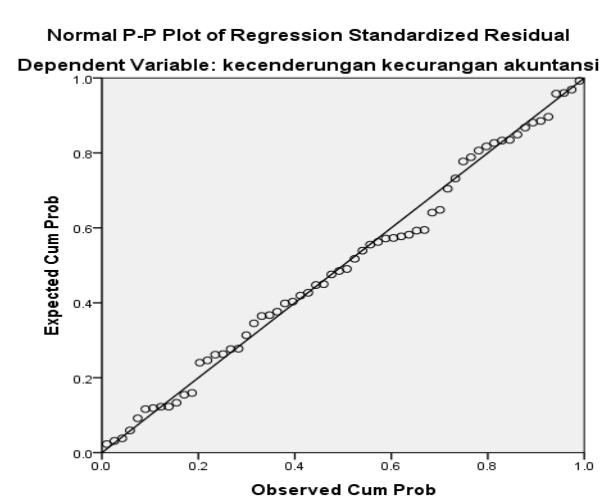

Gambar 2. Diagram Normalitas (Sumber: Data Output SPSS 25, 2020)

Dari gambar Normal PP Plot (Gambar 2) terlihat bahwa titik-titik menyebar disekitar dan mengikut garis diagonal. Hal ini menunjukan bahwa data distribusi normal.

\section{Uji Heterokedastisitas}

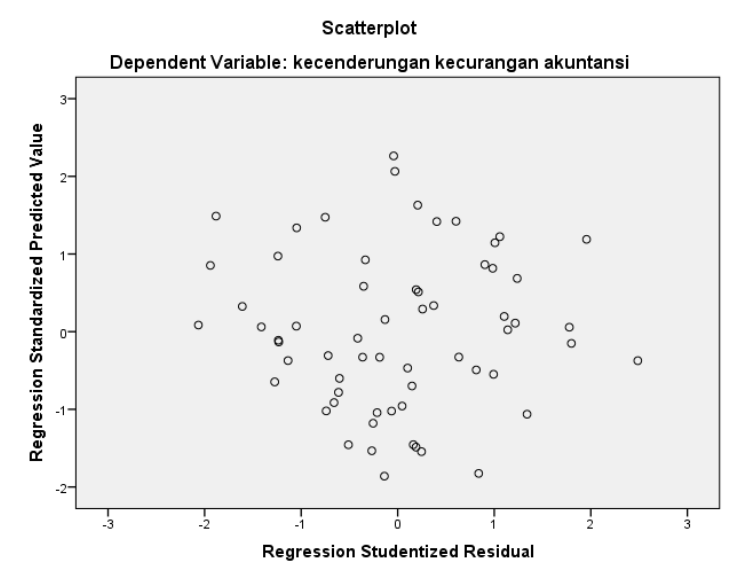

Gambar 3. Hasil Uji Heterokedastisitas (Sumber : Data Output SPSS 25, 2020)

Dari (Gambar 3) dapat dilihat bahwa hasil pengujian heterokedastisitas pada tampilan scatterplot dari variable dependen yaitu kecenderungan kecurangan akuntansi menunjukkan titik-titik menyebar diatas dan dibawah pada sumbu $\mathrm{Y}$, sehingga dapat disimpulkan bahwa model penelitian ini telah terbebas dari heterokedastisitas.

\section{Uji Multikolinearitas}

\begin{tabular}{|c|c|c|c|}
\hline \multicolumn{2}{|c|}{ Tabel 2. Tabel Uji Multikolinearitas } \\
\hline \multirow{2}{*}{ Model } & \multicolumn{2}{|c|}{$\begin{array}{r}\text { Collinearity } \\
\text { Statistics }\end{array}$} & \multirow{2}{*}{ Ket } \\
\cline { 2 - 3 } & $\begin{array}{c}\text { Toler } \\
\text { ance }\end{array}$ & VIF & \\
\hline & & & \\
\hline
\end{tabular}




\begin{tabular}{|c|c|c|c|}
\hline $\begin{array}{l}\text { Keefektifan } \\
\text { Pengendalian } \\
\text { Internal }\end{array}$ & 0.925 & 1.082 & $\begin{array}{l}\text { Bebas } \\
\text { Multi } \\
\text { kolinearitas }\end{array}$ \\
\hline $\begin{array}{l}\text { Ketaatan } \\
\text { Aturan } \\
\text { Akuntansi }\end{array}$ & 0.973 & 1.028 & $\begin{array}{l}\text { Bebas } \\
\text { Multi } \\
\text { kolinearitas }\end{array}$ \\
\hline $\begin{array}{l}\text { Kesesuaian } \\
\text { Kompensasi }\end{array}$ & 0.919 & 1.088 & $\begin{array}{l}\text { Bebas } \\
\text { Multi } \\
\text { kolinearitas }\end{array}$ \\
\hline $\begin{array}{l}\text { Moralitas } \\
\text { Manajemen }\end{array}$ & 0.937 & 1.067 & $\begin{array}{l}\text { Bebas } \\
\text { Multi } \\
\text { kolinearitas }\end{array}$ \\
\hline $\begin{array}{l}\text { Budaya Etis } \\
\text { Organisasi }\end{array}$ & 0.914 & 1.094 & $\begin{array}{l}\text { Bebas } \\
\text { Multi } \\
\text { kolinearitas }\end{array}$ \\
\hline
\end{tabular}

Sumber: Data output SPSS 25,2020

Berdasarkan hasil uji multikolinearitas, maka dapat disimpulkan model regresi tidak terjadi masalah atau bebas multikolinearitas. Hal ini dapat dilihat nilai VIF seluruh variabel independen $<10$, sedangkan nilai Tolerance seluruh variabel independen $>0,1$.

\section{Hasil Analisis Regresi Linier Berganda}

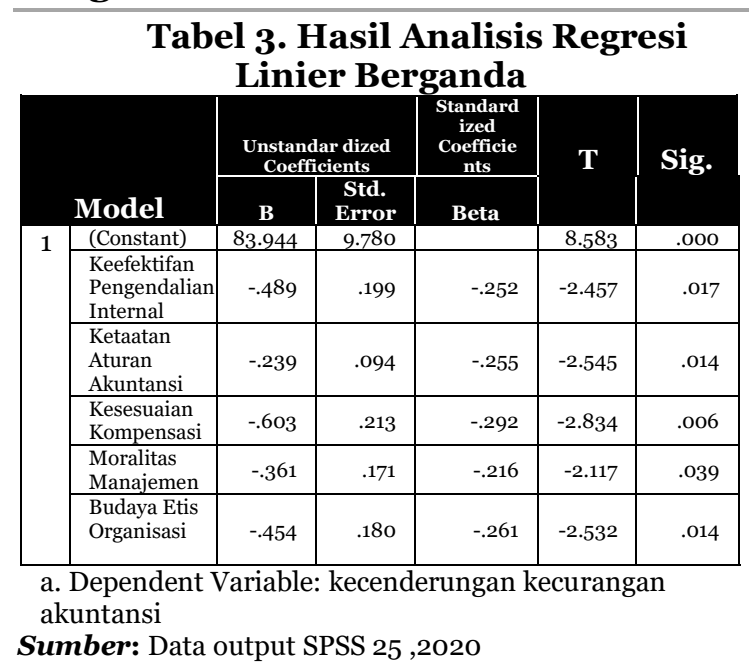

Berdasarkan tabel 3, diperoleh persamaan regresi:

$$
\begin{aligned}
& Y=83,944+(-0,489) X_{1}+(-0,239) \mathrm{X}_{2}+ \\
& \quad(-0,603) \mathrm{X}_{3}+(-0,361) \mathrm{X}_{4}+(-0,454) \mathrm{X}_{5}+e
\end{aligned}
$$

\section{Koefisien Determinasi Simultan $\left(\mathbf{R}^{2}\right)$}

Koefisien determinasi $\left(\mathrm{R}^{2}\right)$ menunjukkan persentase pengaruh variabel independen terhadap variabel dependen yang menunjukkan seberapa besar variabel independen dapat menjelaskan variabel dependennya. Berikut hasil perhitungan koefisien determinasi.

\begin{tabular}{c|c|c|c|c|}
\hline \multicolumn{5}{c}{$\begin{array}{c}\text { Tabel 4. Hasil Perhitungan } \\
\text { Koefisien Korelasi dan } \\
\text { Determinasi Simultan }\end{array}$} \\
\hline Model & $\mathbf{R}$ & $\begin{array}{c}\mathbf{R} \\
\text { Square }\end{array}$ & $\begin{array}{l}\text { Adjusted } \\
\text { R Square }\end{array}$ & $\begin{array}{l}\text { Std. Error of } \\
\text { the Estimate }\end{array}$ \\
\hline 1 & $.674^{\mathrm{a}}$ & .454 & .405 & 6.217 \\
\hline
\end{tabular}

a. Predictors: (Constant), budaya etis organisasi , keefektifan pengendalian internal, ketaatan aturan akuntansi, moralitas manajemen, kesesuaian kompensasi b. Dependent Variable: kecenderungan kecurangan akuntansi

Sumber :Data Output SPSS 25 (2020)

Tabel 4 menunjukkan bahwa nilai adjusted R Square adalah sebesar 0,405 dengan demikian dapat disimpulkan bahwa kecenderungan kecurangan akuntansi dapat dihindarkan dengan adanya beberapa faktor yang dijelaskan dalam penelitian ini yaitu keefektifan pengendalian internal, ketaatan aturan akuntansi, kesesuaian kompensasi, moralitas manajemen dan budaya etis organisasi sebesar 40,5 \% sedangkan sisanya $59,5 \%$ dijelaskan oleh variabel lain yang tidak diamati dalam penelitian ini, seperti Penegakan Hukum, Keadilan Distributif, Asimetri Informasi, Gaya Kepemimpinan, dan Keadilan Prosedural.

\section{Pembahasan}

Hasil analisis hipotesis pertama, keefektifan pengendalian internal berpengaruh terhadap kecenderungan kecurangan akuntansi. Hasil penelitian ini sejalan dengan penelitian Meliany (2013), Rizky Rahmaidha (2016) dan Anna Arifah (2017) bahwa keefektifan pengendalian internal berpengaruh secara signifikan terhadap kecenderungan kecurangan akuntansi pada perusahaan. Namun, tidak sejalan dengan penelitian yang dilakukan oleh Fitri (2016) bahwa keefektifan pengendalian internal tidak berpengaruh secara signifikan terhadap kecenderungan kecurangan akuntansi.

Hasil analisis hipotesis kedua, ketaatan aturan akuntansi berpengaruh 
terhadap kecenderungan kecurangan akuntansi. Hasil penelitian sejalan dengan penelitian Rizky Rahmaidha (2016), Irwansyah (2018) dan Anna Arifah (2017) bahwa Ketaatan Aturan Akuntansi berpengaruh negatif dan signifikan terhadap Kecenderungan Kecurangan Akuntansi. Namun tidak sejalan dengan penelitian Fitri (2016) bahwa ketaatan aturan akuntansi tidak berpengaruh secara signifikan terhadap kecenderungan kecurangan akuntansi.

Hasil analisis hipotesis ketiga, kesesuaian kompensasi berpengaruh terhadap kecenderungan kecurangan akuntansi. Hasil ini sejalan dengan penelitian Meliany (2013) dan Anna Arifah (2017) bahwa Kesesuaian Kompensasi berpengaruh secara signifikan terhadap Kecenderungan Kecurangan Akuntansi. Namun tidak sejalan dengan penelitian yang dilakukan oleh Irwansyah (2018) bahwa Kesesuaian Kompensasi tidak berpengaruh negatif terhadap Kecenderungan Kecurangan Akuntansi.

Hasil analisis hipotesis kempat, moralitas manajemen berpengaruh terhadap kecenderungan kecurangan akuntansi. Hasil ini sejalan dengan penelitian Nelvin, dkk (2020) dan Alou, S. D. (2017) bahwa Moralitas Manajemen berpengaruh terhadap Kecenderungan Kecurangan Akuntansi. Namun tidak sejalan dengan penelitian Irwansyah (2018) yang menyatakan bahwa Moralitas Manajemen tidak berpengaruh negatif terhadap Kecenderungan Kecurangan Akuntansi.

Hasil analisis hipotesis kelima, budaya etis organisasi berpengaruh terhadap kecenderungan kecurangan akuntansi. Hasil ini sesuai dengan penelitian Fachrunnisa (2015) bahwa Budaya Etis Organisasi berpengaruh signifikan terhadap Kecenderungan Kecurangan Akuntansi. Namun tidak sejalan dengan penelitian yang dilakukan oleh Sari, Novita (2018) bahwa Budaya Etis
Organisasi tidak berpengaruh signifikan terhadap Kecenderungan Kecurangan Akuntansi.

\section{SIMPULAN}

Berdasarkan hasil dan pembahasan dapat disimpulkan:

Keefektifan pengendalian internal berpengaruh terhadap kecenderungan kecurangan akuntansi. Hal ini berarti bahwa semakin tinggi keefektifan pengendalian internal yang diterapkan di OPD Kota Pekanbaru maka akan semakin mengurangi terjadinya kecenderungan kecurangan akuntansi.

Ketaatan aturan akuntansi berpengaruh terhadap kecenderungan kecurangan akuntansi. Hal ini berarti bahwa semakin taat OPD Kota Pekanbaru terhadap aturan akuntansi maka akan semakin mengurangi terjadinya kecenderungan kecurangan akuntansi.

Kesesuaian kompensasi berpengaruh terhadap kecenderungan kecurangan akuntansi. Hal ini berarti bahwa semakin sesuai kompensasi yang diberikan kepada para pegawai yang bekerja di OPD Kota Pekanbaru maka akan semakin mengurangi terjadinya kecenderungan kecurangan akuntansi.

Moralitas manajemen berpengaruh terhadap kecenderungan kecurangan akuntansi. Hal ini berarti bahwa semakin tinggi moralitas pegawai yang bekerja di OPD Kota Pekanbaru maka semakin mengurangi terjadinya kecenderungan kecurangan akuntansi.

Budaya etis organisasi berpengaruh terhadap kecenderungan kecurangan akuntansi. Hal ini berarti bahwa semakin baik budaya etis suatu organisasi maka akan semakin mengurangi terjadinya kecenderungan kecurangan akuntansi.

Hasil pengujian koefisien determinasi $\left(\mathrm{R}^{2}\right)$ sebesar 0,405 atau 40,5\%. Hal ini menunjukan bahwa kecenderungan kecurangan akuntansi dapat dihindarkan dengan adanya faktor keefektifan 
pengendalian internal, ketaatan aturan akuntansi, kesesuaian kompensasi, moralitas manajemen dan budaya etis organisasi sebesar 40,5 \% sedangkan sisanya $59,5 \%$ dijelaskan oleh variabel lain yang tidak diamati dalam penelitian ini.

\section{Ucapan Terima Kasih}

Penulis mengucapkan terimah kasih kepada kedua orangtua atas doa dan supportnya dan juga berterimah kasih kepada Prof. Dr. Rita Anugerah, MAFIS., Ak.,CA selaku Pembimbing I dan Nur Azlina, SE., M.Si., Ak., CA selaku Pembimbing II, dan semua pihak yang telah membantu dalam penyusunan penelitian ini.

\section{DAFTAR PUSTAKA}

ACFE Indonesia Chapter 111. (2016). Survai Fraud Indonesia, Association of Certified fraud Examiners.

Alou, S. D., Ilat, V., \& Gamaliel, H. (2017). Pengaruh Kesesuaian Kompensasi, Moralitas Manajemen, Dan Keefektifan Pengendalian Internal Terhadap Kecenderungan Kecurangan Akuntansi Pada Perusahaan Konstruksi Di Manado. GOING CONCERN: JURNAL RISET AKUNTANSI, 12(01).

Arifah, A., \& Rahmawati, D. (2018). Pengaruh Ketaatan Aturan Akuntansi, Keefektifan Pengendalian Internal, Kesesuaian Kompensasi, Keadilan Prosedural, Dan Komitmen Organisasi Terhadap Kecenderungan Kecurangan Akuntansi (Studi pada Perguruan Tinggi Negeri di Daerah Istimewa Yogyakarta). Jurnal Profita: Kajian Ilmu Akuntansi, 6(4).

Arista, Lilik Lia, Titisari, Kartika Hendra dan Suhendro. 2016. Pengaruh Faktor-Faktor Internal Terhadap Kecenderungan Kecurangan Akuntansi Pada PT. Pegadaian Area Surakarta. Seminar Nasional IENACO. 2337-4349.
Fitri, Y. (2016). Pengaruh Keefektifan Sistem Pengendalian Internal, Ketaatan Akuntansi, Asimteri Akuntansi Dan Moralitas Individu Terhadap Kecendrungan Kecurangan Akuntansi dengan Perilaku Tidak Etis Sebagai Variabel Intervening. JOM Fekon, 3 .

Irwansyah, I., \& Syufriadi, B. (2018). Pengaruh Efektivitas Pengendalian Internal, Kesesuain Kompensasi, Moralitas Manajemen, Ketaatan Aturan Akuntansi, Dan Asimetri Informasi Terhadap Kecenderungan Kecurangan Akuntansi. Jurnal Akuntansi, 8(2), 89-100.

Meliany, Lia \& Herna Ernawati. 2013. Pengaruh Keefektifan Pengendalian Internal dan Kesesuaian Kompensasi Terhadap Kecenderungan Kecurangan Akuntansi. Journal \& Proceeding Universitas Jenderal Soedirman, Vol III, No.1. Hal.1-10.

Pramudita, Aditya. (2013). Faktor-faktor yang Mempengaruhi Terjadinya Fraud di Sektor pemerintahan (Persepsi Pegawai pada dinas se-kota salatiga). Universitas Negeri Semarang.

Rahayu, N. P., Probowulan, D., \& Mahara, A. (2020). Pengaruh Sistem Pengendalian Intern, Kesesuaian Kompensasi dan Moralitas Manajemen terhadap Kecenderungan Kecurangan Akuntansi (Studi Empiris pada Perbankan di Kabupaten Jember). Jurnal Akuntansi Profesi, 11(2).

Rahmaidha, R., \& Sukirno, S. (2017). Pengaruh keefektifan pengendalian internal, ketaatan aturan akuntansi, dan kepuasan kerja terhadap kecurangan akuntansi. Jurnal Profita: Kajian Ilmu Akuntansi, 5(4). Riauterkini.2020. "Kejati Riau Umumkan Dua Tersangka Dugaan Korupsi Video Wall Pemko Pekanbaru”. 
http://riauterkini.com.Diunduh tanggal 6 Febuari 2020.

Robbins, Stephen P dan Judge, Timothy A. 2008. Perilaku Organisasi Organi zational Behaviour. Penerbit: Salemba Empat. Jakarta.

Safitri, D., Hasan, A., \& Fachrunisa, A. (2015). Pengaruh Keefektifan Pengendalian Internal, Keadilan Distributif, Keadilan Prosedural, dan Budaya Etis Organisasi terhadap Kecenderungan Kecurangan (Fraud) Akuntansi (Studi Empiris pada SKPD Kabupaten Kampar) (Doctoral dissertation, Riau University).

Sari, R. N. (2018). Pengaruh Budaya Etis Organisasi, Penegakan Hukum Dan Asimetri Informasi Terhadap Kecendrungan Kecurangan Akuntansi (Fraud) (Studi Empiris pada Satuan Kerja Perangkat Daerah Kota Padang Panjang). Jurnal Akuntansi, 6(3).Simanjuntak, S. N. (2015). Pengaruh Independensi, Kompetensi, Skeptisme Profesional dan Profesionalisme Terhadap Kemampuan MendeteksiKecurangan (Fraud) Pada Auditor di BPK RI Perwakilan Provinsi Sumatera Utara. Jom FEKON.

Sugiyono. 2014. Metode Penelitian Administrasi. Bandung: CV Alfabeta. Thoyibatun, Siti. 2012. "Faktor-Faktor yang Berpengaruh Terhadap Perilaku Tidak Etis dan Kecenderungan Kecurangan Akuntansi serta Akibatnya Terhadap Kinerja Organisasi”. Jurnal Ekonomi dan Keuangan, Vol: 16, No. 2. Hal. 245 260.

Veithzal Rivai. (2011). Manajemen Sumber Daya Manusia Untuk Perusahaan. Jakarta: PT. Rajagrafindo Persada.

Wilopo, 2006. Faktor-Faktor yang Berpengaruh Terhadap Kecenderungan Kecurangan Akuntansi : Studi Pada Perusahaan Publik dan Badan Usaha Milik
Negara, SNA IX Padang, STIE Pebanas, Surabaya. 